\title{
Design and Biological Evaluation of 2,2'-Dinitrodiphenylmethane Derivatives
}

\author{
A. JEPA MALAR ${ }^{* a}$, M. CHRISTUDHAS ${ }^{\mathrm{a}}$ and G. ALLEN GNANA RAJ ${ }^{\mathrm{b}}$
}

${ }^{a}$ Department of Chemistry, N. M. Christian College, Marthandam, Tamilnadu-629165, India

${ }^{\mathrm{b}}$ Department of Chemistry, Scott Christian College (Autonomous),

Nagercoil, Tamilnadu-629003, India

malarjepa@gmail.com

Received 13 November 2012 / Accepted 15 December 2012

\begin{abstract}
Synthesis of 4,4',5,5'-tetrabromo-2,2'-dinitrodiphenylmethane and 5,5'-dibromo-2,2'dinitrodiphenylmethane from 4,4'-diamino-5,5'-dibromo-2,2'-dinitrodiphenylmethane are reported. 4,4',5,5'-Tetrabromo-2,2'-dinitrodiphenylmethane (TBNDPM) have been synthesized by a simple and convenient method employing Sandmeyer's reaction of 4,4'-diamino-5,5'-dibromo-2,2'dinitrodiphenylmethane (ABNDPM) with cuprous bromide and hydrobromic acid and 5,5'-dibromo2,2'-dinitrodiphenylmethane (BNDPM) has obtained by treatment of ABNDPM with hypophosphorous acid and cuprous oxide. The structures of the synthesized compounds are assigned on the basis of elemental and spectral analysis (UV-visible, FTIR and ${ }^{1} \mathrm{H}$-NMR). The synthesized compounds have been evaluated for the antibacterial and antifungal efficacy.
\end{abstract}

Keywords: Sandmeyer's reaction, Cuprous bromide, Hydrobromic acid, Hypophosphorous acid, Antimicrobial activity

\section{Introduction}

The chemistry of 2,2'- dinitrodiphenylmethane compounds had been investigated extensively for the last several decades leading to new synthetic routes, variety of structures and their potential biological applications ${ }^{1-4}$. Nitroaromatics are hazardous chemicals that display several manifestations of toxicity, including skin sensitization ${ }^{5}$, immunotoxicity ${ }^{6}$, germ cell degeneration $^{7}$, inhibition of liver enzymes ${ }^{8}$ and also a conjectured carcinogenicity ${ }^{9}$. Nitro aromatic compounds are cytotoxic, it has been proposed that their cytotoxicity is due to the generation of reactive oxygen species such as superoxide radical anion, singlet oxygen and hydrogen peroxide ${ }^{10}$. Possible formation of highly mutagenic or carcinogenic nitrocompounds is unquestionably of great environmental interest ${ }^{11}$. Antibacterial and antifungal diseases are very common all over the world. A number of diphenylmethane derivatives have been synthesized that exhibit antipsychotic activities ${ }^{12}$. Nitro compounds have a wide variety of applications ranging from food preservatives to antibiotics. Nitroimidazoles have therapeutic uses as anaerobic antibacterial and antiprotozoal agents ${ }^{13}$. 
They have other interesting biological activities of therapeutic potential such as radio sensitizers in treatment of cancer ${ }^{14-16}$, control of fertility ${ }^{17}$ and antitubercular therapy ${ }^{18}$. The highly selective effect of this drug is due to reduction of these drugs by nitro reductase enzymes resulting in the formation of highly reactive free radical species ${ }^{19,20}$. Although there is no carcinogenicity or mutagenicity of metranidazole in human beings ${ }^{21}$, it has been shown to be mutagenic in bacteria and carcinogenic in rodents ${ }^{22}$. In the present study $2,2^{\prime}$-dinitrodiphenylmethane derivatives have been synthesized and the structures of these derivatives were assigned on the basis of elemental analysis, UV-visible, FTIR and ${ }^{1} \mathrm{H}-\mathrm{NMR}$ spectral data. The synthesized compounds were screened for their antimicrobial activities.

\section{Experimental}

All the chemicals used were of AR grade obtained from Merck, India and were used without further purification. The melting points of the compounds were determined by digital Auto Melting point apparatus, Labronies. The purity of the synthesized compounds were checked by TLC using silica gel "G" as adsorbent and visualizing through Heber Scientific Mini UV viewer. IR spectra were recorded on a Perkin-Elmer Precisely Spectrum 100 in the 4000 $400 \mathrm{~cm}^{-1}$ region. UV -visible spectra were obtained on a Perkin - Elmer Lamda 750 UV Vis spectrometer using dimethyl sulphoxide as solvent in the $200-800 \mathrm{~nm}$ regions. The ${ }^{1} \mathrm{H}$ NMR spectral analysis were performed on a JEOL 300 JMTC - 300 / 54 spectrometer using tetramethyl silane as internal standard. Chemical compositions of the synthesized compounds were carried out using Hitachi S-4800 field emission scanning electron microscope (FE-SEM) equipped with EMAX elemental analyzer.

\section{Synthesis of 4,4'-diamino-5,5'-dibromo-2,2'-dinitrodiphenylmethane (ABNDPM)}

4,4'-Diamino-3,3'-dibromodiphenylmethane was prepared from 2-bromoaniline and formaldehyde using standard procedure. 4,4'-Diamino-3,3'-dibromodiphenylmethane was nitrated ${ }^{23}$ using a mixture of anhydrous potassium nitrate and $98 \%$ sulphuric acid at $0{ }^{\circ} \mathrm{C}$. A solution of potassium nitrate $(0.05 \mathrm{~mol})$ in conc. $\mathrm{H}_{2} \mathrm{SO}_{4}(18 \mathrm{~N})$ at $0{ }^{\circ} \mathrm{C}$ was added to an ice-cold solution of 4,4'diamino-3,3'-dibromodiphenylmethane $(0.025 \mathrm{~mol})$ in conc. $\mathrm{H}_{2} \mathrm{SO}_{4}(18 \mathrm{~N})$ drop wise over a period of half an hour with stirring. The stirring was continued for another three hours, keeping the reaction mixture at $0{ }^{\circ} \mathrm{C}$. The reaction mixture was diluted by pouring it over crushed ice and was then neutralized with ice-cold ammonia solution (1:1). The orange yellow solid was filtered, washed thoroughly with water and dried (Scheme 1). This product was recrystallised from ethyl alcohol-ethyl acetate mixture (90:10) and that furnished orange red flakes of 4,4'-diamino-5,5'-dibromo-2,2'-dinitrodiphenylmethane ${ }^{24}$ (m.p. $215^{\circ} \mathrm{C}$ ) was formed.

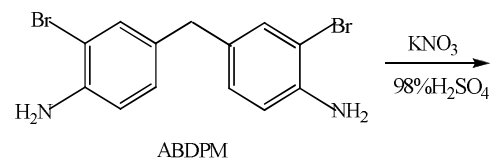<smiles>Nc1cc(Br)c(Cc2cc(Br)c(N)cc2O[N+](=O)[O-])cc1Br</smiles>

ABNDPM

Scheme 1. Synthesis of ABNDPM

\section{Synthesis of 4,4',5,5'-tetrabromo-2,2'-dinitrodiphenylmethane (TBNDPM)}

4,4'-Diamino-5,5'-dibromo-2,2'-dinitrodiphenylmethane (ABNDPM) (8.14 g) dissolved in 1:1 hydrobromic acid $(30 \mathrm{~mL})$ was diazotized at $0{ }^{\circ} \mathrm{C}$ with sodiumnitrite $(16.9 \mathrm{~g})$. The reaction mixture was then added to a cold solution of cuprous bromide $(11.6 \mathrm{~g})$ in conc. $\mathrm{HBr}(30 \mathrm{~mL})$, gave a crude product (Scheme 2) which was chromatographed on a column of neutral alumina using petroleum ether-benzene $(5: 1 \mathrm{v} / \mathrm{v})$ as eluant ${ }^{25}$. The product thus obtained was crystallized from benzene -petroleum ether $(1: 10 \mathrm{v} / \mathrm{v})$ as pale yellow plates (m.p. $\left.260{ }^{\circ} \mathrm{C}\right)$. 
<smiles>Nc1cc2c(cc1N)Cc1cc(Br)c(N)cc1OC2</smiles>

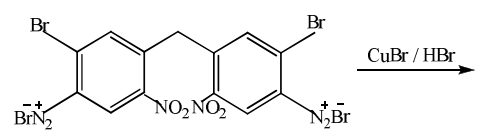<smiles>Brc1cc2c(cc1Br)Cc1cc(Br)c(Br)cc1OC2</smiles>

Scheme 2. Synthesis of TBNDPM

\section{Synthesis of 5,5'-dibromo-2,2'-dinitrodiphenylmethane (BNDPM)}

To a solution of 4,4'-diamino-5,5'-dibromo-2,2'-dinitrodiphenylmethane (8.15 g) in hypophosphorous acid $(50 \%, 200 \mathrm{~mL})$ cuprous oxide $(2.5 \mathrm{~g})$ was added. The mixture was cooled to $0{ }^{0} \mathrm{C}$ and a solution of sodium nitrite $(18 \mathrm{~g})$ in water $(25 \mathrm{~mL})$ was added drop wise over a period of half an hour with constant stirring. (Scheme 3) The stirring and cooling was continued for another three hours when the evolution of nitrogen ceased. The mixture was then extracted repeatedly with benzene and the solvent removed under reduced pressure. The residue was chromatographed on a column of neutral alumina using petroleum ether as the eluant. 5,5'-Dibromo-2,2'-dinitrodiphenylmethane obtained from the eluate was crystallized from benzene -petroleum ether $(1: 10)$ as pale yellow needles ${ }^{26}$ (m.p. $154^{\circ} \mathrm{C}$ ).
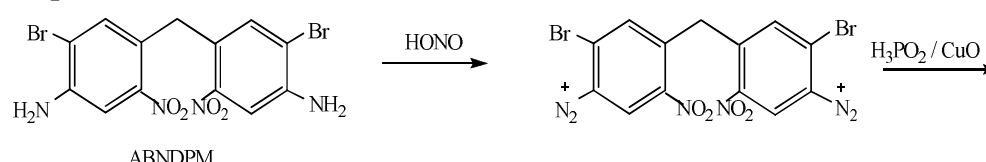<smiles>O=[N+]([O-])c1ccc(Br)cc1Cc1cccc(Br)c1</smiles>

Scheme 3. Synthesis of BNDPM

\section{Antimicrobial screening}

The in vitro antimicrobial activity of the synthesized 2,2'-dinitrodiphenyl methane derivatives on selected bacteria Pseudomonas aeruginosa (NCIM 2026), Proteus vulgaris (NCIM 2027), Staphylococcus aureus (NCIM 2127), Klebsiella pneumonia (NCIM 5082) and Escherichia coli (NCIM 2563) and two fungi Penicillium notatum (NCIM 745) and Aspergillus niger (NCIM 616) was carried out. The antimicrobial action was studied by sterile disc method using concentration of $1 \mathrm{mg} / \mathrm{mL}$. The test solution was prepared in ethanol. These discs were placed on the already seeded plates and incubated at $37{ }^{\circ} \mathrm{C}$ for $24 \mathrm{~h}$ for the bacterial strain and at $27{ }^{\circ} \mathrm{C}$ for $42 \mathrm{~h}$ to $72 \mathrm{~h}$ for the fungal strain. Amikacin was used as a standard for antibacterial screening and flucanazole was used as a standard for antifungal screening. The growth of the microbes was measured by recording the diameter of the inhibition zone. The results are represented in terms of activity index.

$$
\text { Activity Index }(\mathrm{AI})=\frac{\text { Inhibition zone of the sample }}{\text { Inhibition zone of the standard }}
$$

\section{Results and Discussion}

The most obvious approach for carrying out the synthesis of substituted $2,2^{\prime}$-dinitrodiphenylmethanes is due to potent biological activity of nitro group. The mechanism for the synthesis is given below. The molecular formula is obtained from elemental analysis. The elemental analysis, molecular formula and melting points are given in Table 1. The compounds are also characterized by spectral analysis. The spectral data are also given in Table 2. 
Table 1. Analytical data of the synthesised compounds

\begin{tabular}{|c|c|c|c|c|c|c|c|}
\hline \multirow{2}{*}{ Sample code } & \multicolumn{5}{|c|}{ Elemental Abalysis, \% } & \multirow{2}{*}{$\begin{array}{c}\text { Molecular } \\
\text { Formula }\end{array}$} & \multirow{2}{*}{$\begin{array}{l}\text { Melting } \\
\text { Point, }{ }^{\circ} \mathrm{C} \\
\end{array}$} \\
\hline & $\mathrm{C}$ & $\mathrm{H}$ & $\mathrm{N}$ & $\mathrm{O}$ & $\mathrm{Br}$ & & \\
\hline ABNDPM & 34.98 & 2.25 & 12.59 & 14.33 & 35.85 & $\mathrm{C}_{13} \mathrm{H}_{10} \mathrm{~N}_{4} \mathrm{O}_{4} \mathrm{Br}_{2}$ & 215 \\
\hline TBNDPM & 27.19 & 1.07 & 4.9 & 11.14 & 55.7 & $\mathrm{C}_{13} \mathrm{H}_{4} \mathrm{~N}_{2} \mathrm{O}_{4} \mathrm{Br}_{4}$ & 260 \\
\hline BNDPM & 37.58 & 1.89 & 6.71 & 15.35 & 38.47 & $\mathrm{C}_{13} \mathrm{H}_{6} \mathrm{~N}_{2} \mathrm{O}_{4} \mathrm{Br}_{2}$ & 154 \\
\hline
\end{tabular}

Table 2. Infrared and UV-visible spectra of synthesised compounds

\begin{tabular}{|c|c|c|c|c|c|c|c|c|c|c|c|}
\hline \multirow[b]{2}{*}{$\begin{array}{l}\text { Sample } \\
\text { code }\end{array}$} & \multicolumn{10}{|c|}{ Frequency of the peak, $\mathrm{cm}^{-1}$} & \multirow[b]{2}{*}{ 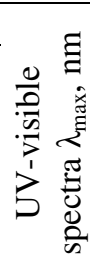 } \\
\hline & 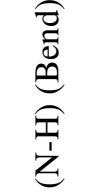 & 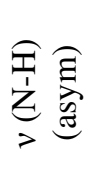 & 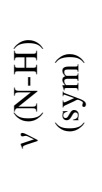 & 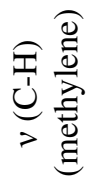 & 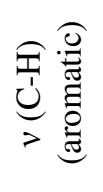 & 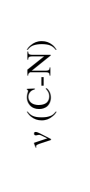 & 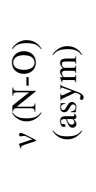 & 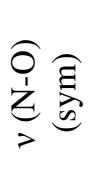 & 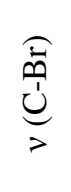 & $\underbrace{\stackrel{0}{U}}_{>}$ & \\
\hline$\overline{A B N D P M}$ & 1620 & 3350 & 3500 & 1465 & 3200 & 1175 & 1523 & 1347 & 650 & - & 380 \\
\hline TBNDPM & - & - & - & 1450 & 3100 & - & 1525 & 1300 & 600 & - & 337 \\
\hline BNDPM & - & - & - & 1400 & 3080 & - & 1523 & 1347 & 550 & - & 322 \\
\hline
\end{tabular}

\section{Characterization}

\section{4,4'-Diamino-5,5'-dibromo-2,2'-dinitrodiphenylmethane}

Elemental analysis: Found: C, 34.98; H, 2.25; N,12.59; O, 14.33; Br, 35.85; Calculated: C, 35.01; H, 2.24; N, 12.56, O,14.35; Br, 35.83 UV-visible $380 \mathrm{~nm}$; FTIR v(cm $\left.{ }^{-1}\right) 1620(\mathrm{~N}-\mathrm{H}$ bend), $3350(\mathrm{~N}-\mathrm{H}$ asym), $3500(\mathrm{~N}-\mathrm{H}$ sym), 1465 (C-H of methylene), $3200(\mathrm{C}-\mathrm{H}$ of $\mathrm{Ar}-\mathrm{H})$, 1175 (C-N), 1523 (N-O asym), 1347 (N-O sym) 650 (C-Br); ${ }^{1} \mathrm{H}-\mathrm{NMR}: \delta$ (ppm) 3.43 (s,2H,Ph-CH $-\mathrm{Ph}), 4.20$ (s,4H,NH ), 7.23-7.63 (m,4H,Aromatic).

\section{4,4',5,5'-Tetrabromo-2,2'-dinitrodiphenylmethane}

Elemental analysis: Found: C, 27.19; H, 1.07; N,4.9; O, 11.14; Br, 55.7; Calculated: C, 27.21; H, 1.05; N, 4.88; O,11.15; Br, 55.71. UV-visible $337 \mathrm{~nm}$; FTIR v( $\left.\mathrm{cm}^{-1}\right) 1450(\mathrm{C}-\mathrm{H}$ of methylene), 3100 (C-H of Ar-H), 1525 (N-O asym), 1300 (N-O sym), 600 (C-Br); ${ }^{1} \mathrm{H}-\mathrm{NMR}$ : $\delta(\mathrm{ppm}) 3.39$ (s,2H,Ph- $\left.\mathrm{CH}_{2}-\mathrm{Ph}\right), 7.29-8.43$ (m, 4H, Aromatic).

\section{5,5'-Dibromo-2,2'-dinitrodiphenylmethane}

Elemental analysis: Found: C, 37.58; H, 1.89; N,6.71; O, 15.35; Br, 38.47; Calculated: C, 37.54; H, 1.92; N, 6.73; O, 15.38; Br, 38.42. UV-visible $322 \mathrm{~nm}$; FTIR v( $\left.\mathrm{cm}^{-1}\right) 1400(\mathrm{C}-\mathrm{H}$ of methylene), 3080 (C-H of Ar-H), 1523 (N-O asym), 1347 (N-O sym), 550(C-Br); ${ }^{1} \mathrm{H}-\mathrm{NMR}$ : $\delta$ (ppm) 3.55 (s,2H,Ph- $\left.\mathrm{CH}_{2}-\mathrm{Ph}\right), 7.29-8.43$ (m, 4H, Aromatic).

\section{Antimicrobial activity studies}

The results of the antibacterial and antifungal screening of the 2,2'-dinitrodiphenylmethane derivatives with Pesudomonas aeruginosa, Proteus vulgaris, Staphylococcus aureus, Klbsiella pneumonias, Escherichia coli, Penicillium notatum and Aspergillus niger by sterile disc method are given in Table 3. The synthesized compounds exhibited varying degree of antibacterial and antifungal activity against the test organisms. The zone of inhibition differs with respect to the different positions of the substituents of 2,2'-dinitrodiphenylmethane derivatives. ABNDPM shows the highest antibacterial activity with the zone of inhibition 
$16 \mathrm{~mm}$ against Escherichia coli and antifungal activity with the zone of inhibition $12 \mathrm{~mm}$ against Penicillium notatum. TBNDPM shows the highest antibacterial activity with the zone of inhibition $16 \mathrm{~mm}$ against Staphylococcus aureus and antifungal activity with the zone of inhibition $12 \mathrm{~mm}$ against Penicillium notatum. BNDPM shows the highest antibacterial activity with the zone of inhibition $18 \mathrm{~mm}$ against Staphylococcus aureus and antifungal activity with the zone of inhibition $10 \mathrm{~mm}$ against Penicillium notatum. From the Table 3 it is clear that all the newly synthesized compounds are highly active against the bacteria Staphylococcus aureus and the fungi Penicillium notatum. According to overtons concept of cell permeability, the lipid membranes that surround the cell favors the passage of only the lipid soluble material due to which lipid solubility is an important factor, which control antimicrobial activity ${ }^{4}$.

Table 3. In vitro antimicrobial activity of compounds and their inhibition zone in $\mathrm{mm}$

\begin{tabular}{|c|c|c|c|c|c|c|c|c|}
\hline \multirow{3}{*}{ Microorganism } & \multicolumn{8}{|c|}{ Zone of inhibition, $\mathrm{mm}$} \\
\hline & \multicolumn{2}{|c|}{ ABNDPM } & \multicolumn{2}{|c|}{ TBNDPN } & \multicolumn{2}{|c|}{ DNDPM } & \multirow{2}{*}{ Amikacin } & \multirow{2}{*}{ Flucanazole } \\
\hline & $\mathrm{ZI}$ & $\mathrm{AI}$ & ZI & $\mathrm{AI}$ & ZI & $\mathrm{AI}$ & & \\
\hline $\begin{array}{l}\text { Pseudomonas } \\
\text { aeruginosa }\end{array}$ & 10 & 0.4 & 10 & 0.4 & 8 & 0.32 & 25 & - \\
\hline Proteus valgaris & 10 & 0.4 & 12 & 0.48 & 15 & 0.6 & 25 & - \\
\hline Staphylococcus aureus & 13 & 0.46 & 16 & 0.57 & 18 & 0.64 & 28 & - \\
\hline Klebsiella pneumoniae & 11 & 0.55 & 15 & 0.75 & 15 & 0.75 & 20 & - \\
\hline Escherichia coli & 16 & 0.57 & 10 & 0.36 & 10 & 0.36 & 28 & - \\
\hline Penicilium notatum & 12 & 0.6 & 12 & 0.6 & 10 & 0.5 & - & 20 \\
\hline Aspergillus niger & 10 & 0.56 & 10 & 0.56 & 8 & 0.44 & - & 18 \\
\hline
\end{tabular}

\section{Conclusion}

New 2,2'-dinitrodiphenylmethane derivatives have been synthesized and characterized by UV-Visible, IR and ${ }^{1} \mathrm{H}$ NMR spectral analysis. The antimicrobial data show that all these compounds were active against pathogenic species. Moreover, the studies show the significant antimicrobial activity to Staphylococcus aureus and Penicillium notatum. Among the synthesised compound BNDPM shows highest antibacterial activity and TBNDPM shows highest antifungal activity. The compounds also inhibit the growth of fungi and bacteria to a greater extent as the concentration is increased. The compounds can be used as potent antibacterial and antifungal agents. Further study is needed for the identification of active site. It is essential to predict the leading molecule and drug like property at the onset of drug design which will helps in drug development.

\section{References}

1. Ferrari M B, Capacchi S, Bisaglic F and Pelosi G P, Inorg Chim Acta, 2001, 81, 312.

2. Vadim Yu Kukushkin and Armando J L Pombeiro, Coord Chem Rev., 1999, 181(1), 147-175.

3. Vandim Yu Kukushkin and Armando J L Pombeiro, Coord Chem Rev., 1996, 156, 333.

4. Shakru R, Subhashini N J P, Sathish Kumar K and Shivaraj, J Chem Pharm Res., 2010, 2(1), 38-46.

5. Cronin M T D, Gregory B W and Schultz T W, Chem Res Toxicol., 1998, 11(8), 902-908.

6. Li Q, Minami M, Hanaoka T and Yamamura Y, Toxicol., 1999, 137, 35-45. 
7. Shinoda K, Mitsumori K, Yasuhara K, Uneyama C, Onodera H, Takegawa K, Takahashi M and Umemura T, Arch Toxicol., 1998, 72, 296-302.

8. Sajan M, Reddy G and Kulkarni A P, Int J Toxicol., 2000, 19, 285-292.

9. Ohkuma Y and Kawanishi S, Biochem Biophys Res Commun., 1999, 257, 555-560.

10. Sies H and Degroot H, Toxicol Lett., 1992, 64-65, 547-551.

11. Matykiewiczova N, Romana Kurková, Jana Klánová and Petr Klán, J Photochem Photobiol A: Chem., 2007, 187(1), 24-32.

12. Ashutosh Kar, Medicinal Chemistry, New Age International Publishers, 2005, 715; ISBN: 8122415652

13. Celik A and Aras Ates N, Drug Chem Toxicol., 2006, 29(1), 85-94.

14. Adams G E, Radiat Res., 1992, 132(2), 129-139.

15. Adams G E and Stratford I J, Biochem Pharmacol., 1986, 35(1), 71-76.

16. Adams G E and Stratford I J, Int J Radiat Oncol Biol Phys., 1994, 29(2), 231-238.

17. Kapoor N K, Chadha R, Venisetty P K and Prasanth S, J Sci Ind Res., 2003, 62, 659-665.

18. Nagarajan K, Shankar R G, Rajappa S, Shenoy S T and Costu-Pereira R, Eur J Med Chem., 1989, 24, 631-633.

19. Miller M, Surgery, 1983, 93, 185-171.

20. Edward D I, Biochem Pharmacol., 1986, 35(1), 53-58.

21. Petri W A Jr, Trends Parasitol., 2003, 19(11), 523-526.

22. Rustia M and Shubik P, J Natl Cancer Inst., 1972, 48(3), 721-729.

23. Ehrlichand P and Bauer H, Ber Dtsch Chem Ges., 1915, 48, 502-507.

24. Sudheesh Kumar K, Orient J Chem., 2010, 26(4), 1393-1399.

25. Catala A and Popp F D, J Heterocycl Chem., 1964, 1, 178.

26. Theliacker W and Korndorfer O, Tetrahedron Lett., 1959, 5. 